\title{
EFEKTIVITAS PENDEKATAN SAINTIFIK BERBASIS GROUP INVESTIGATION DAN DISCOVERY LEARNING DITINJAU DARI MINAT BELAJAR MAHASISWA
}

\author{
Ira Vahlia ${ }^{1)}$, Yeni Rahmawati ES ${ }^{2)}$, Tri Anjar ${ }^{3)}$ \\ 1), 2) Pendidikan Matematika FKIP Universitas Muhammadiyah Metro \\ ${ }^{3)}$ Pendidikan Bimbingan dan Konseling FKIP Universitas Muhammadiyah Metro \\ E-mail: iravahlia768@yahoo.co.id ${ }^{1)}$,yeni.rahmawati1988@yahoo.com ${ }^{2)}$, \\ trianjar69@yahoo.com ${ }^{3)}$
}

\begin{abstract}
Appropriate learning models contribute to student learning interest in math. The purpose of this study is to describe the difference in effectiveness between scientific approach based on group investigation and discovery in terms of student's interest in learning. The research that is conducted is quasi experimental research and the design used is $2 x$ factorial description. In experimental class I that apply scientific approach model based on study group investigation obtained the average value of learning outcome of 66.60 while in the experimental class II applying the approach Sciencebased discovery learning obtained the average value of posttest of 76.28. Based on the marginal rate, the scientific approach to discovery-based learning on moderate interest in learning outcomes is higher than the learning outcomes at high and low interest. In the scientific approach based on group study investigation and discovery learning there are differences in average learning outcomes between high, medium and low interest. Scientific approach based on group investigation learning on higher interest in learning outcomes is higher than moderate and low interest.
\end{abstract}

Keywords: discovery learning, group investigation, interest to learn, saintific approach

\section{PENDAHULUAN}

Pemerintah selalu melakukan inovasi dalam dunia pendidikan, misalnya dengan memperkenalkan berbagai pendekatan dan model pembelajaran inovatif. Dalam upaya mencapai tujuan pendidikan, hendaknya pendidik dalam kegiatan pembelajarannya menguasai bahan ajar dan teori-teori belajar yang dikemukakan oleh para ahli. Menguasai bahan yang akan diajarkan merupakan syarat essensial bagi guru matematika, tetapi penguasaan materi belumlah cukup untuk dapat membawa peserta didik berpartisipasi secara intelektual dalam pembelajaran.
Sebenarnya apa yang mahasiswa lihat, dengar, pikir, sebagian tergantung pada konsep-konsep atau gagasan-gagasan yang telah dimiliki mahasiswa sebelumnya.

Salah satu faktor agar mahasiswa matematika terampil dalam mengajar secara efektif, ia harus menguasai materi SMP dan SMA secara benar. Masalah yang muncul dalam perkuliahan telaah kurikulum SMP di semester 4 ini masih banyak mahasiswa yang belum menguasai cara membelajarkan materi SMP yang terdiri dari materi lingkaran, relasi dan fungsi, statistika, dan lain-lain.

$$
\text { Data lengkap tanggapan } 74
$$


ISSN 2089-8703 (Print) Vol. 6, No. 1 (2017)

ISSN 2442-5419 (Online)

mahasiswa terhadap kondisi awal perkuliahan disajikan pada Tabel 1

Tabel 1. Tanggapan Mahasiswa Matematika tentang Kondisi Perkuliahan

\begin{tabular}{|c|l|c|c|}
\hline \multirow{2}{*}{ No } & \multicolumn{1}{|c|}{ Kondisi Perkuliahan } & \multicolumn{2}{|c|}{ Keterangan } \\
\cline { 2 - 4 } & $\begin{array}{l}\text { Ya } \\
\text { telaah kurikulum }\end{array}$ & 73 & 1 \\
\hline 2 & $\begin{array}{l}\text { Mahasiswa mengalami kesulitan dalam } \\
\text { mengajar materi telaah kurikulum SMP }\end{array}$ & 70 & 4 \\
\hline 3 & $\begin{array}{l}\text { Mahasiswa menganggap konsep matematika } \\
\text { sebagai sumber kesulitan }\end{array}$ & 65 & 9 \\
\hline 4 & $\begin{array}{l}\text { Mahasiswa mengetahui aplikasi pembelajaran } \\
\text { telaah kurikulum SMP }\end{array}$ & 24 & 50 \\
\hline 5 & $\begin{array}{l}\text { Mahasiswa mempunyai minat yang tinggi } \\
\text { dalam pembelajaran telaah kurikulum SMP }\end{array}$ & 4 & 70 \\
\hline
\end{tabular}

Dari analisis data di atas mahasiswa calon guru matematika sebagian besar mengetahui tujuan perkuliahan sebanyak 98,64\%. Namun mahasiswa banyak yang mengalami kesulitan dalam mengajar materi, serta menganggap konsep matematika sebagai sumber kesulitan. Dapat dilihat juga bahwa sebanyak 32,4\% mahasiswa mengetahui aplikasi pembelajaran telaah kurikulum SMP dan hanya 5,4\% mahasiswa yang memiliki minat dalam pembelajaran telaah kurikulum SMP dikarenakan memang sudah pernah dipelajari pada waktu SMP.

Nitko \& Brookhart (2007: 448) menyatakan bahwa minat merupakan pilihan terhadap bentuk-bentuk tertentu dari suatu aktifitas ketika seseorang tidak sedang berada dalam tekanan dari luar dirinya. Minat merupakan aspek afektif yang menunjang keberhasilan belajar mahasiswa. Mahasiswa yang memiliki minat belajar yang baik terhadap pelajaran akan merasa senang mempelajari mata pelajaran tersebut sehingga diharapkan akan mencapai hasil belajar yang optimal. Hal ini terjadi karena aktivitas yang dilakukan mahasiswa didorong oleh suatu kekuatan dari dalam diri mahasiswa.

Hasil dan minat belajar mahasiswa menjadi permasalahan yang harus segera diselesaikan. Jika tidak diselesaikan, mahasiswa tidak akan belajar dengan sebaik- baiknya karena minatnya rendah sehingga hasil belajar yang diperoleh kurang maksimal. Dengan demikian diperlukan model pembelajaran yang dapat meningkatkan hasil dan minat belajar mahasiswa terhadap matematika. (Sagala, 2011: 68) menyatakan bahwa pendekatan pembelajaran mempermudah bagi dosen memberikan pelayanan belajar dan juga mempermudah bagi mahasiswa untuk memahami materi ajar yang disampaikan dosen, dengan memelihara suasana pembelajaran yang menyenangkan

Salah satu pendekatan pembelajaran matematika yang dapat meningkatkan hasil dan minat belajar matematika adalah pendekatan saintifik berbasis group investigation dan discovery. Gerde (2013: 317) menjelaskan bahwa metode scientific adalah suatu proses untuk bertanya dan 
menjawab pertanyaan dengan menggunakan kumpulan prosedur yang spesifik. Jika ada sesuatu yang muncul yang tidak dipahami dengan baik, spekulasikan tentang penjelasannya dan kemudian temukan beberapa cara untuk mencoba spekulasi tersebut. Lebih lanjut Carey (2011: 3) menjelaskan bahwa pada tingkat yang paling dasar, metode scientific cukup sederhana, terdiri dari tiga langkah proses. Dimulai dengan mengamati secara hati-hati beberapa bagian dari alam.

Pendekatan saintifik merupakan suatu cara atau mekanisme untuk mendapatkan pengetahuan dengan prosedur yang didasarkan pada metode ilmiah. Pendekatan saintifik terdapat 5 langkah utama yaitu : (1) Mengamati (observing), (2) Menanya (questioning), (3) Mengumpulkan informasi (eksperimenting), (4) Mengolah informasi (associating), dan (5) Mengkomunikasikan. Karena dalam pendekatan ini mahasiswa sendiri yang membangun pengetahuan barunya berdasarkan pengetahuan dan pengalaman sebelumnya, serta diskusi kelompok. Menurut Menurut Thobroni (2011: 295) "model group investigation melibatkan mahasiswa sejak perencanaan, baik dalam menentukan topik maupun cara untuk mempelajari melalui ivestigasi. Model ini menuntut mahasiswa untuk memiliki kemampuan yang baik dalam berkomunikasi maupun dalam keterampilan proses berkelompok (group process skill).“ Model pembelajaran berbasis group investigation merupakan proses berpikir berdasarkan pertanyaan yang muncul dari permasalahan, dan menggunakan berbagai sumber untuk bahan pembelajaran sehingga memberikan waktu kepada mahasiswa untuk berpikir dan merespon serta saling membantu satu sama lain. Menurut Ecylopedia of Educational Research (dalam Asmani,
2011: 155), penemuan merupakan "suatu strategi yang unik dan dapat diberi bentuk oleh dosen dalam berbagai cara termasuk mengajarkan keterampilan menyelidiki dan memecahkan masalah." Model discovery merupakan suatu cara untuk mengembangkan cara belajar mahasiswa aktif dengan menemukan sendiri, menyelidiki sendiri, maka hasil yang akan diperoleh akan tahan lama dalam ingatan, tidak mudah dilupakan mahasiswa.

Berdasarkan uraian diatas, dengan pendekatan saintifik berbasis group investigation dan discovery diperkirakan mampu mendukung dalam meningkatkan hasil dan minat belajar matematika mahasiswa. Oleh karena itu, akan dilakukan penelitian tentang "keefektifan pendekatan saintifik berbasis group investigation dan discovery ditinjau dari minat belajar mahasiswa".

\section{METODE PENELITIAN}

\section{Tahapan-Tahapan Penelitian}

Tahapan pelaksanaan penelitian sebagai berikut:

\section{Tahap perencanaan}

Tahap perencanaan meliputi: observasi objek penelitian, penyusunan usulan penelitian, pengajuan izin penelitian, pengambilan data nilai awal belajar matematika mahasiswa, penyusunan instrumen, penyesuaian skenario pembelajaran dan instrumen dengan dosen di tempat penelitian.

2. Tahap pelaksanaan

Dalam penelitian ini menerapkan pendekatan saintifik berbasis group investigation, discovery sebanyak enam kali pertemuan. Lima kali digunakan untuk pembelajaran dan satu kali digunakan untuk tes hasil belajar dan memberikan angket minat. Tahap pelaksanaan meliputi: uji coba instrumen dan pengumpulan data. 
3. Analisis data dan Penyusunan Laporan

Mengolah dan menganalisis data penelitian berupa data angket minat dan hasil belajar mahasiswa kemudian menguji hipotesis dan mengambil kesimpulan.

\section{Lokasi Penelitian}

Penelitian dilaksanakan di Universitas Muhammadiyah Metro dengan waktu penelitian direncanakan mulai dari bulan Mei sampai dengan Oktober 2017.

\section{Model yang Digunakan}

Populasi dalam penelitian ini adalah seluruh mahasiswa semester 4 Universitas Muhammadiyah Metro yang terdiri dari kelas A dengan 27 mahasiswa dan kelas Bdengan 29 mahasiswa Tahun Pelajaran 2017/2018. Teknik pengambilan sampel menggunakan teknik simple random sampling dimana peneliti mengambil sampel secara acak dengan sistem pengundian. Pelaksanaan pada penelitian ini kelompok eksperimen I diberi perlakuan dengan pendekatan saintifik berbasis group investigation dan kelompok eksperimen II diberikan perlakuan pendekatan berbasis discovery learning. Desain penelitian yang digunakan adalah pretest-posttest nonequivalent group design. Pada setiap kelompok dilakukan pretest dan posttest.

\section{Rancangan Penelitian}

Rancangan penelitian ini menggunakan rancangan faktorial $2 \mathrm{x}$ 3. faktor pertama adalah pendekatan saintifik berbasis group investigation dan discovery learning. Faktor kedua adalah minat tinggi, sedang dan rendah. Rancangan dalam penelitian ini dapat digambarkan sebagai berikut:

Tabel 2. Rancangan Faktorial 2 x 3

\begin{tabular}{|l|c|c|c|}
\hline \multicolumn{1}{|c|}{ Pembelajaran } & \multicolumn{3}{|c|}{ Minat $(\boldsymbol{b})$} \\
\cline { 2 - 4 } & Tinggi $\left(\boldsymbol{b}_{\mathbf{1}}\right)$ & Sedang $\left(\boldsymbol{b}_{\mathbf{2}}\right)$ & Rendah $\left(\boldsymbol{b}_{\mathbf{3}}\right)$ \\
\hline $\begin{array}{l}\text { Pendekatan Saintifik berbasis } \\
\text { Group Investigation }\left(\boldsymbol{a}_{1}\right)\end{array}$ & $(\mathrm{ab})_{11}$ & $(\mathrm{ab})_{12}$ & $(\mathrm{ab})_{13}$ \\
\hline $\begin{array}{l}\text { Pendekatan Saintifik berbasis } \\
\text { Discovery }\left(\mathbf{a}_{2}\right)\end{array}$ & $(\mathrm{ab})_{21}$ & $(\mathrm{ab})_{22}$ & $(\mathrm{ab})_{23}$ \\
\hline
\end{tabular}

\section{Teknik Pengumpulan Data}

Teknik pengumpulan data adalah cara-cara yang digunakan untuk mengumpulkan data. Data penelitian ini dikumpulkan melalui teknik tes dan non tes (angket).

1) Teknik tes digunakan untuk memperoleh data hasil belajar.

2) Teknik Non tes (angket) digunakan untuk memperoleh data minat mahasiswa

\section{Analisis Data}

Pengolahan data kuantitatif dilakukan dengan menggunakan uji anava dua jalan dengan sel tak sama untuk menentukan uji statistik yang akan digunakan, terlebih dahulu diuji normalitas dan homogenitas. Analisis data hasil tes dilakukan untuk mengetahui perbedaan peningkatan hasil belajar antara mahasiswa yang mendapatkan pembelajaran saintifik berbasis group investigation dan discovery. Analisis data akan dilakukan dengan menggunakan bantuan Software SPSS 19 for windows, yaitu dengan melakukan uji normalitas, uji 
homogenitas, serta uji hipotesis.

\section{HASIL PENELITIAN DAN PEMBAHASAN}

Berikut ini disajikan tentang hasil penelitian yang telah dilaksanakan. Adapun hasil penelitian adalah deskripsi data, hasil uji coba instrumen, analisis data dan pembahasan penelitian.

\section{Hasil Uji Coba Instrumen Penelitian}

Uji coba instrumen ini dilakukan pada mahasiswa semester 6 dengan jumlah subjek sebanyak 50 mahasiswa. Instrumen yang diujicobakan dalam penelitian ini adalah instrumen tes hasil belajar dan angket minat. Hasil uji coba untuk masing-masing instrumen adalah sebagai berikut : Instrumen tes hasil belajar matematika yang disusun oleh peneliti berbentuk essay dan terdiri dari 5 butir soal. Instrumen tes hasil belajar matematika yang diujicobakan.

\section{Uji Validitas Instrumen Tes}

Validasi dilakukan oleh: 1) Bapak Nurain Suryadinata, M. Pd. Dosen Pendidikan Matematika Universitas Muhammadiyah Metro, 2) Bapak Nego Linuhung, M. Pd. Dosen Pendidikan Matematika Universitas Muhammadiyah Metro, 3) Ibu Fhela Fhantoria Ningrum Dosen Pendidikan Matematika Universitas Muhammadiyah Kotabumi. Validasi dilakukan untuk mengetahui tingkat kelayakan tes hasil belajar serta angket minat yang digunakan dalam penelitian yang mengalami beberapa revisi dari ketiga dosen tersebut.

Tabel 3 Nilai Hasil Validasi Tes Hasil Belajar

\begin{tabular}{|c|l|c|}
\hline No & \multicolumn{1}{|c|}{ Nama } & Kategori \\
\hline 1 & Nurain Suryadinata, M. Pd & Sangat Layak \\
\hline 2 & Nego Linuhung, M. Pd. & Layak \\
\hline 3 & Fhela Fhantoria, M. Pd. & Sangat Layak \\
\hline \multicolumn{2}{|c|}{ RATA-RATA } & Sangat Layak \\
\hline
\end{tabular}

Dari hasil validasi tersebut, maka tes hasil belajar matematika ini telah siap untuk di uji coba dan digunakan pada mahasiswa dalam perkuliahan telaah kurikulum matematika.

\section{Uji Validitas Instrumen Angket Minat}

Berdasarkan validasi angket minat mahasiswa oleh 3 validator, dari 30 butir angket terdapat 5 butir yang tidak layak digunakan. Sehingga butir angket yang terpakai untuk penelitian yaitu 25 butir angket yang terdiri dari pernyataan positif dan negatif.

\section{Hasil Pretest Mahasiswa \\ Deskripsi Data Kemampuan Awal Matematika Mahasiswa}

Data kemampuan awal
matematika mahasiswa diperoleh dari Nilai Mid Semester. Berikut disajikan deskripsi data kemampuan awal matematika siswa pada kelas eksperimen Satu dan Dua

Tabel 4. Deskripsi Data Kemampuan Awal Matematika Siswa

\begin{tabular}{|l|r|c|c|c|c|}
\hline $\begin{array}{c}\text { Model } \\
\text { Pembelajaran }\end{array}$ & $\boldsymbol{n}$ & $\begin{array}{c}\text { Nilai } \\
\text { Min }\end{array}$ & $\begin{array}{l}\text { Nilai } \\
\text { Maks }\end{array}$ & Rerata & Standar Deviasi \\
\hline Discovery & 27 & 40 & 80 & 63,15 & 8,565 \\
\hline GI & 29 & 45 & 80 & 62,24 & 7,972 \\
\hline
\end{tabular}

\section{Deskripsi Data Minat Awal Mahasiswa}


Data minat awal mahasiswa diperoleh dari penyebaran angket setelah dilakukan Mid Semester. Data minat awal mahasiswa. Berikut disajikan deskripsi data minat awal mahasiswa pada kelas eksperimen satu dan dua.

Tabel 5 Deskripsi Data Minat Awal Mahasiswa

\begin{tabular}{|l|c|c|c|c|c|}
\hline $\begin{array}{c}\text { Model } \\
\text { Pembelajaran }\end{array}$ & $\boldsymbol{n}$ & $\begin{array}{c}\text { Nilai } \\
\text { Min }\end{array}$ & $\begin{array}{c}\text { Nilai } \\
\text { Maks }\end{array}$ & Rerata & Standar Deviasi \\
\hline Discovery & 27 & 30 & 72 & 54,11 & 10,646 \\
\hline GI & 29 & 34 & 71 & 56,76 & 9,694 \\
\hline
\end{tabular}

\section{Deskripsi Data Penelitian}

Mengingat pengujian hipotesis juga melibatkan interaksi antar masingmasing model pembelajaran dan minat, maka selain deskripsi data tersebut juga disajikan deskripsi data hasil belajar matematika mahasiswa pada perpaduan masing-masing model pembelajaran sebagai berikut:

Tabel 6 Deskripsi Data Hasil Belajar Matematika Mahasiswa pada Masing-Masing Model Pembelajaran dan Minat

\begin{tabular}{|c|c|c|c|c|}
\hline \multirow{4}{*}{ Model Pembelajaran } & \multirow{2}{*}{ Tinggi } & Sedang & Rendah \\
\hline \multirow{4}{*}{ Discovery } & $n$ & 16 & 7 & 4 \\
\cline { 2 - 5 } & Nilai Min & 60 & 65 & 60 \\
\cline { 2 - 5 } & Nilai Maks & 100 & 95 & 80 \\
\cline { 2 - 5 } & $\bar{x}$ & $\mathbf{7 6 , 8 8}$ & $\mathbf{8 0 , 7 1}$ & $\mathbf{7 1 , 2 5}$ \\
\cline { 2 - 5 } & $s$ & 12,37 & 10,58 & 10,31 \\
\hline \multirow{4}{*}{$\boldsymbol{G I}$} & $n$ & 8 & 12 & 9 \\
\cline { 2 - 5 } & Nilai Min & 60 & 55 & 45 \\
\cline { 2 - 5 } & Nilai maks & 90 & 85 & 80 \\
\cline { 2 - 5 } & $\bar{x}$ & $\mathbf{7 0 , 6 3}$ & $\mathbf{6 7 , 5 0}$ & $\mathbf{6 1 , 6 7}$ \\
\cline { 2 - 5 } & $s$ & 10,84 & 8,39 & 12,25 \\
\hline
\end{tabular}

\section{Uji Hipotesis Penelitian}

Pengujian hipotesis dilakukan untuk mengetahui apakah terdapat perbedaan pengaruh antar masingmasing kategori model pembelajaran dan Minat serta interaksinya terhadap hasil belajar matematika. Hasil perhitungan uji hipotesis dengan analisis variansi dua jalan dengan sel tak sama dan taraf signifikansi $\alpha=0,05$ disajikan pada tabel sebagai berikut: 
Tabel 7. Rangkuman Analisis Variansi Dua Jalan dengan Sel Tak Sama

\begin{tabular}{|l|c|c|c|}
\hline \multicolumn{1}{|c|}{ Sumber } & $F_{\text {hit }}$ & $F_{\text {tabel }}$ & Keputusan Uji \\
\hline $\begin{array}{l}\text { Model } \\
\text { Pembelajaran }(A)\end{array}$ & 43,450 & 3,0000 & Ho ditolak \\
\hline Minat $(B)$ & 11,510 & 3,0000 & Ho ditolak \\
\hline Interaksi $(A B)$ & 18,700 & 2,3700 & Ho ditolak \\
\hline Galat $(G)$ & - & - & \\
\hline Total & - & - & \\
\hline
\end{tabular}

Berdasarkan pada Tabel di atas diperoleh bahwa:

a. Nilai $F_{a}=43,450$ dan $F_{\text {tabel }}=3,00$, ternyata $F_{a}>F_{\text {tabel }}$ dengan demikian $H_{0 A}$ ditolak. Hal ini berarti pada tingkat signifikansi $\alpha=0,05$, model pembelajaran discovery dan group investigation memberikan efek yang berbeda terhadap hasilpembelajaran.

b. Nilai $F_{b}=11,510$ dan $F_{\text {tabel }}=3,00$, ternyata $\quad F_{b}>F_{\text {tabel }}$ dengan demikian $H_{0 B}$ ditolak. Hal ini berarti pada tingkat signifikansi $\alpha=0,05$, Minat tinggi, sedang, dan rendah memberikan efek yang berbeda terhadap belajar hasi 1 pembelajaran.

c. Nilai $F_{a b}=18,700 \quad$ dan $F_{\text {tabel }}=2,37$, ternyata $F_{a b}>F_{\text {tabel }}$ dengan demikian $H_{0 A B}$ ditolak. Hal ini berarti pada tingkat signifikansi $\alpha=0,05$, terdapat interaksi antara model pembelajaran dan kategori Minat mahasiswa terhadap hasil pembelajaran.

\section{Hasil Uji Komparasi Ganda}

Dari rerata marginal hasil belajar matematika siswa yang yang memiliki Minat sedang, yakni 74,10 lebih besar dibandingkan rerata marginal hasil belajar matematika mahasiswa yang yang memiliki Minat rendah, yakni 66,46. Dengan demikian, diperoleh simpulan bahwa hasil belajar matematika mahasiswa yang yang memiliki Minat sedang lebih baik dibandingkan mahasiswa yang memiliki Minat rendah.

Berdasarkan hasil penelitian dan pengujian hipotesis, berikut adalah penjelasan dari hipotesis penelitian. Hasil analisis variansi dua jalan dengan sel tak sama menunjukkan bahwa terdapat perbedaan pengaruh antar masing-masing kategori model pembelajaran terhadap hasil belajar matematika mahasiswa. Berdasarkan hasil uji komparasi rerata antar baris pada masing-masing model pembelajaran, diperoleh simpulan bahwa hasil belajar matematika mahasiswa yang dikenai model pembelajaran discovery lebih baik dibandingkan hasil belajar matematika mahasiswa yang dikenai model pembelajaran group investigation.

Berdasarkan hasil uji komparasi rerata antar kolom pada masing-masing Minat, diperoleh simpulan bahwa hasil belajar matematika mahasiswa yang memiliki Minat sedang lebih baik dibandingkan hasil belajar matematika mahasiswa yang memiliki Minat tinggi dan rendah, dan hasil belajar matematika mahasiswa yang memiliki Minat sedang lebih baik dibandingkan hasil belajar matematika mahasiswa yang memiliki Minat rendah.

\section{KESIMPULAN DAN SARAN}

Dari hasil penelitian dapat disimpulkan bahwa: 
1. Pada kelas eksperimen I yang menerapkan pendekatan saintifik model berbasis pembelajaran group investigation diperoleh nilai ratarata hasil belajar sebesar 66,60 sedangkan pada kelas eksperimen II yang menerapkan pendekatan saintifik berbasis discovery learning diperoleh nilai rata-rata postest sebesar 76,28.

2. Tidak terdapat perbedaan yang signifikan antara hasil belajar mahasiswa pada kelas yang menerapkan pendekatan saintifik berbasis discovery learning dan kelas yang menerapkan model pembelajaran pendekatan saintifik berbasis group investigation pada mata kuliah telaah kurikulum.

Dari hasil penelitian yang diperoleh, maka peneliti memberikan saran sebagai berikut: Pada kegiatan pembelajaran dengan menerapkan pendekatan saintifik berbasis discovery learning sebaiknya semua mahasiswa dalam satu kelompok harus memiliki sumber materi lebih banyak selain dari buku referensi yang berasal dari dosen. Pada kegiatan model pembelajaran pendekatan saintifik berbasis discovery learning ketika menyelesaikan masalah sebaiknya siswa dipasangkan dengan teman yang tingkat kemampuannya berbeda atau heterogen supaya proses pembelajaran dapat berlangsung dengan lancar.

\section{DAFTAR PUSTAKA}

Asmani. 2011. Tips Menjadi Dosen Inspiratif Kreatif dan Inovatif. Yogyakarta: DIVA Press.

Carey, S. S. 2011. A Beginner's Guide to Scientific Method (4th). Wadsworth Cengage learning.

Gerde, H.K., Schachter, R.E., Wasik, B.A. 2013. "Using the Scientific Method to Guide Learning: An Integrated
Approach to Early Childhood Curriculum". Early Childhood Education Journal. Volume 41 No. 5. Hal 315-323.

Nitko, A.J. \& Brookhart, S.M. 2007. Educational asessment of students. New Jersey: Pearson Education.

Sagala, Syaiful. 2011. Konsep dan Makna Pembelajaran. Bandung : Alfabeta

Thobroni, M., dan Mustofa, A. 2011. Belajar dan Pembelajaran Pengembangan Wawancara dan Praktik Pembelajaran dalam Pembangunan Nasional. Jogjakarta: Ar-Ruzz Media. 